\title{
Low Molecular Weight Phosphotyrosine Protein Phosphatase
}

National Cancer Institute

\section{Source}

National Cancer Institute. Low Molecular Weight Phosphotyrosine Protein Phosphatase.

NCI Thesaurus. Code C88197.

Low molecular weight phosphotyrosine protein phosphatase (158 aa, $18 \mathrm{kDa}$ ) is

encoded by the human ACP1 gene. This protein is involved in the removal of

orthophosphate from both flavinoids and proteins. 